\title{
EMPLACEMENT AND IMPLICATIONS OF ULTRA-DEEP XENOLITHS AND DIAMONDS FROM THE TRANSITION ZONE.
}

\author{
Haggerty, Stephen E. \\ Dept. of Geology, Univ. of Massachusets, Amherst, MA 01003 U.S.A.
}

The recognition of high-Si garnet inclusions in diamonds from Monastery (Moore and Gurney, 1985) and Jagersfontein (Tsai et al., 1985; Moore et al., 1991, in press) in South Africa, and from San Luiz in Brazil (Wilding et al., 1989), and of pyroxene exsolved from garnets in xenoliths from Jagersfontein (Haggerty and Sautter, 1990; Sautter et al., 1991; Sautter and Haggerty, this volume), provides a basis for the evaluation of transport mechanisms and the timing of sample entrainment from the transition zone at depths between 400 and $650 \mathrm{~km}$. These ultra-deep samples have significant implications for petrochemical models of the upper mantle, diamond genesis and kimberlite evolution.

There are at least three possible origins for the transition zone: (I) it is isochemical with the upper mantle, but not the lower mantle, and represents a series of phase changes to higher density polymorphs; (2) it is a primoidial interface that resulted from fractionation of the core and differentiation of the upper mantle from the lower mantle; or (3) it was created by the bouyancy-equivalent piling up of subducted oceanic slabs. In none of these cases is this zone likely to contain an abundance of heat-producing elements. Therefore, the only viable mechanism for the transport of ultra-deep xenolitins and diamonds from regions in the vicinity of the transition zone $(>300 \mathrm{~km})$ is by plume activation arising from instabilities in the $D^{\prime}$ layer at the core-mantle boundary.

Kimberlites are becoming increasingly accepted as plume-driven melts from the upper mantle. These bodies have been geochemically linked to ocean island basalts and share the distinction with plateau basalts erupted at the onset of continental fragmentation, inasmuch as tectonism and melt generation are both plume-activated (Duncan and Richards, 1991). Major plumes are invoked to account for flood basalts of the Karoo in southern Africa, and plume paths are documented by le Roex (1986). The most prominent plumes on the SE margin of the Kaapvaal Craton that were active at about the time $(100 \mathrm{Ma})$ of the Jagersfontein kimberlite eruptions were the Shona, Bouve and Marion hot spots. We attach particular significance to the location of the Jagersfontein and Monastery kimberlite pipes at the edge of the craton with the association of ultra-deep xenoliths and excess-si garnets in diamonds. It was at the edge of the craton that the plumes were most vigorous as attested to by the ensuing separation of Madagscar and Antarctica from southern Africa during the Mesozoic. If plumes are indeed generated in the $D^{\prime \prime}$ layer at the core-mantle boundary 12900 $\mathrm{km})$ then mechanical transport of xenoliths from the region of the relatively shallow transition zone $(400 \mathrm{~km})$ would not 
appear to be a significant obstacle. The thermal regime and the initial sizes of bodies entrained in the plume may, however, be critical to xenolith survival. Physical entrainment of mantle xenoliths is a new proposal. Plumes are most commonly considered to be only agents of heat transfer, but if melts are produced (e.g.. Campbell et al., 1989) and relative viscosities are appropriate to solid media transport, xenolith entrainment is inevitable. Rising plumes on intersection with the transition zone are likely to mushroom because of thermal dissipation. It is critical to sampling of this horizon that temperatures range from liquidus to sub-liquidus, vertically and laterally, throughout the zone. Other barriers and horizons of interference are at the lithosphere-asthenosphere boundary ( $L A B)$, and at $75-100 \mathrm{~km}$ in the lithosphere in the region of the LILE and HFSE metasomes (LHM). It is either at the LAB or the LHM that garnet-bearing xenoliths equilibrated to form pyroxene lamellae from previously homogeneous high-Si garnets. (Sautter and Haggerty, this volume).

Plumes do not appear to be affected on geological time scales by whole mantle convection (e.g., Olson et al., 1988), thus sustained thermal activity at and within the sub-cratonic lithosphere should be expected. While the volatile content of the transition zone remains unknown, indications from OIBs is that plumes are geochemically enriched. Even with subduction, the transition zone is unlikely to be a source of volatiles because of dehydration and progressive melt extraction of the down-going slab. Therefore, enrichment is very likely derived directly from the D" layer. We propose that this is the main source of volatiles for melt metasomatism of depleted lithosphere. Continued activity might result in extensive metasomatism at the base of the lithospheric keel or tectosphere until some critical threshold is reached in which plumes are transformed to what we now designate as flumes (wet hot spots) and kimberlites are injected. Primary transport of the ultra-deep samples was by plumes, and following equilibration (i.e., exsolution of pyroxene from garnet) by flumes.

Some other possibly important implications for volatiles originating from the D" layer are: (1) a source of. C for micro-diamonds, and diamonds in some classes of eclogites; (2) the ubiquitous presence of sulfides as diamond inclusions; (3) erosion at the base of subcratonic lithospheric keel and penetration of diamond-etching and diamond-dissolution fluids and melts: (4) a more rational. explanation for the sources of volatiles in LILE and HFSE metasomatizing melts and cube diamond overcoats at higher levels in the lithosphere: (5) a possibly exotic mechanism for carbon isotopic fractionation: and (6) a more viable scurce for SiC, $\mathrm{Fe}$, and magnesiowüstite-ferropericlase inclusions in diamonds. Eclogitic diamonds are of diverse origin, and distinctions in diamond-entrapment ages between some eclogitic and ultramafic diamonds may well be related to a global plume event at $\sim 1.5 \mathrm{Ga}$, followed by particularly vigorous flume activity and kimberlite eruptions at $-1.0 \mathrm{Ga}$, and again at $100 \mathrm{Ma}$. Kimberlite and lamproite eruptions in specific time frames on a global basis can now perhaps be best explained if the timing of eruptions is linked to the geometry of plume instabilities from the $D^{\prime \prime}$ layer. 
The link between and among basalts, OIBs, kimberlites, plumes and plate tectonics is enormously strengthened by the recognition of asthenospherically-derived diamonds and of xenoliths from the transition zone (TZ). If plumes are primarily responsible for diamond eruptives, an inevitable ccnclusion is that all such eruptives have a high probahility of containing transition zone renoliths (TZX); but this raises an interesting question on the apparent absence of eclogitic or TzX-based diamonds in off-craton kimberlites. One possibility is that off-craton intrusions have a greater opportunity for interaction with oxidizing asthenosphere (Haggerty, 1986): below cratons and in the continental keel model (e.g., Haggerty, 1986), the asthenospheric interval between the base of the keel and the $\mathrm{TZ}$ is of the order of $200 \mathrm{~km}$; in the tectosphere model (Jordan, 1975), the interval may be only kilometers thick or may not be present at all; whereas in off-craton regions the interval is about $400 \mathrm{~km}$. Nonetheless, we propose that TZXs are widespread but that because of extensive equilibration, these xenoliths are more generally described as garnet harzburgite, garnet lherzolite, garnet pyroxenite, and eclogite. If the transition zone is to be fully characterized, future studies should concentrate on developing techniques and establishing criteria to unequivocally distinguish between ultra-deep xenoliths and those derived from shallower horizons.

\section{REFERENCES}

Campbell, L.H., Griffiths, R.W. and Hill, R.L. (1989) Melting in an Archean mantle plume: heads it's basalts, tails i¿'s komatiites. Nature 339, 697-699.

Duncan, R.A. and Richards, M.A. (1991) Hot spots, mantle plumes, flood basalts and true polar wander. Rev. Geophys. 29, 31-50.

Haggerty, S.E. (1986) Diamond genesis in a multiply constrained model. Nature $320,34-38$.

Haggerty, S.E. and Sautter, V. (1990) Ultra-deep (>300 km) ultramafic, upper mantle xenoliths. Science, 248 , 993-996.

Jordan, T.H. (1978) Composition and development of the continental tectosphere. Nature 274, 544-548.

le Roex, A. (1986) Geochemical correlation between southern African kimberlites and South Atlantic hotspots. Nature $324,243245$.

Moore, R.O. and Guerney, J.J. (1985) Pyroxene solid solution in garnets included in diamonds. Nature 318, 553-555.

olson, P.. Schubert, G.. Anderson, C. and Goldman, P. (1988) Plume formation and lithosphere erosion: A comparison of laborabory and numerical experiments. J. Geophys. Res. $93,15,065-15,084$.

Sautter, V. and Haggerty, S.E. (1991) Ultra-deep (>300 km) ultramafic xenoliths: New petrologic evidence from the transition zone. Science, in press.

Tsai, H., Meyer, H.O.A. Moreau, J. and Milledge, H.J. (1979) Mineral inclusions in diamond: Premier, Jagersfontein and Finsch kimberlites, South Africa, and Williamson Mine, Tanzania: In Boyd and Meyer, eds. Kimberlites, Diatremes and Diamonds. 1, 16-26. AGU. Washington, D.C.

Wilding, M.C.. Harte, B. and Harris, J.W. (1989) Evidence of asthenospheric source for diamonds from Brazil. Extended Abs. IGC. 3,359-360. 